This is a draft chapter / article. The final version is available in Frontiers in European Entrepreneurship Research edited by Laveren, Eddy , Blackburn, Robert, Hytti, Ulla and Landstrom, Hans, published in 2019, Edward Elgar Publishing Ltd

https://doi.org/10.4337/9781789903980.00019

The material cannot be used for any other purpose without further permission of the publisher, and is for private use only. 


\title{
11. FREELANCING AND THE STRUGGLE FOR WORK-TIME CONTROL $^{1}$
}

\author{
John Kitching \& Marfuga Iskandarova
}

\section{INTRODUCTION}

Freelance workers, defined as independent own-account workers who provide goods and services alone (or with co-owning partners) but do not employ others, are the most common form of small business (Kitching and Smallbone 2012). Freelancers have been major drivers of UK job growth in the years 2001-16 (ONS 2018a), much of it in 'privileged' rather than 'precarious' sectors (Tomlinson and Corlett 2017). UK Labour Force Survey data suggest there were 4.06 million freelance workers in main jobs in Q4, 2017 (ONS 2018b), an increase of more than one million since Q4, 2008, the period immediately prior to the start of the recession resulting from the global financial crisis. But despite their growing numbers, and a substantial presence in all sectors of the economy, freelancers have been a minority interest among small business researchers, because of their lower visibility, and policymaker and academic interest in business growth. A developing stream of research has however begun to investigate these nanobusinesses, their characteristics, activities and relationships (Fraser and Gold 2001; Barley and Kunda 2006; Burke 2012; Armstrong 2013), including studies of the so-called 'gig economy', where freelancers find and win projects using online platforms (CIPD 2017; Broughton 2018; Burtch et al. 2018). We seek to contribute to this research stream by exploring freelancers' experiences of operating the very smallest firms, in particular, the management of working time.

Freelance working reflects, in part, a desire to enjoy greater control over working life (Benz and Frey 2008; Stephan et al. 2015; Taylor 2017). Popular and media discourses often assume freelancers possess the autonomy to choose what work they do, who they work for, and how, where and when they work (Dellot 2014; O'Leary 2014; Lenton 2017). Control over working time is one important dimension of freelancer autonomy (Evans et al. 2004; van Gelderen and Jansen 2006) and a source of greater meaningfulness in work (Bailey and Madden 2017). But because freelancers are responsible for generating their own work and income, they must contribute the 
labour time necessary to satisfy a portfolio of fee-paying clients sufficient to sustain a subjectively acceptable livelihood. This can give rise to an 'autonomy paradox' (Huws et al. 1996) whereby freelancers choose to work long or 'unsocial' hours to ensure market survival (Shevchuk et al. 2019).

We conceptualise freelancer-client relations in terms of a struggle for work-time control. Freelancers seek to valorise their labour time by taking on new projects, while also resisting 'client colonisation' of non-working time (Gold and Mustafa 2013), as clients simultaneously seek to elicit freelancer effort to ensure prompt project completion. Unlike employees who negotiate the use of their time with a single employer, freelancers must choose how to allocate their time between multiple clients and projects. The outcome of work-time control struggles is uncertain; assumptions that freelance working necessarily leads to either a high degree of control over work-time, or conversely no control at all, therefore need to be investigated rather than assumed.

This study explores the struggle for work-time control in two professional sectors, architecture and publishing. Given the diversity of the freelance population (Kitching 2016; Vermeylen et al. 2017; Williams et al. 2017; Bögenhold 2019), we might hypothesise that freelancer control of work-time varies considerably. Occupations requiring the exercise of high levels of skills and judgement - those we might describe as 'privileged' rather than 'precarious' - might be expected to permit freelancers to exert substantial work-time control. If highly skilled, professional freelancers lack control of working time, those in less-skilled occupations might be expected to possess even less. Researching these two groups provides a strong test of arguments about freelancer autonomy and flexibility. We seek to answer the following two questions:

- What practices do freelancers engage in to control work-time?; and

- How do relations with clients influence freelancer capacity to control worktime?

The chapter is structured as follows. First, we review the literature on freelancing and identify a number of research gaps related to relations with clients that facilitate or frustrate freelancer attempts to control working time. Next, we develop an analytical framework linking client type and resources, client demand for freelancers' services, and two interdependent dimensions of working time which freelancers seek to control - work duration and work-time scheduling. We then set out our methodological 
approach and present the main findings before concluding and drawing out the implications for theory and research.

\section{FREELANCING, CONTROL OF WORKING TIME AND CLIENT RELATIONS}

People work freelance for a variety of reasons, including to have greater control over working time (van Gelderen and Jansen 2006; Sappleton and Lourenço 2016; Kautonen et al. 2017; Lenton 2017). ${ }^{2}$ Cohen (2019) suggests that freelance work is characterised by temporal and spatial unboundedness, that is, work activities are not demarcated by formal time and space boundaries; work can be performed at different times and in different places. Cohen emphasises unboundedness as a structural component of freelance work, rather than an incidental by-product or a consequence of freelancer choice. Work activities that are temporally unbounded lend themselves to being organised on a freelance, rather than an employment, basis. Occupations vary in their temporal boundedness, contingent upon whether work needs to be performed where clients or co-workers are present, or where immobile plant and machinery must be used (Cohen 2019). Hence freelancers in different occupations, varying in temporal unboundedness, might be expected to differ in their capacity to control working time. Home-based freelance working, for example, allows greater control over work scheduling than working at client premises (Osnowitz and Henson 2016) and homebased freelancers enjoy high levels of time flexibility (Mason and Reuschke 2015).

Research on working time is typically discussed in terms of work-life, workfamily and work-retirement balance. This literature largely refers to employees but can easily be extended to freelance workers who are presumed to possess greater time flexibility than employees because they are not tied to employers' workplace routines (Baines and Gelder 2003). Work-life balance issues vary across the life course for both men and women related to career stage, family stage and biological ageing (Darcy et al. 2012). Freelancing might be considered suitable for prime working-age men who can take on as many projects as they can manage to increase earnings to support a family, for working mothers who take primary responsibility for childcare (Bell and La Valle 2003), for those seeking to combine paid work with caring for elderly relatives 
(Dellot 2014), and for older workers seeking to enact a 'phased retirement' (Keohane 2017) or a better 'work-retirement' balance (Wainwright and Kibler 2014).

A dominant research theme has therefore been the contradiction between the prospect of freelancers' time sovereignty and the reality of demands on working time (Osnowitz and Henson 2016). Possessing the legal right to determine one's working time cannot guarantee a satisfying work-life balance (Annink and den Dulk 2012; FSB 2016). Where freelancers perceive 'time as money' (Bailey and Madden 2017), or as an 'expense' (Hilbrecht and Lero 2014), their control of work-time may be limited because they feel a persistent pressure to take on more projects to generate income. Many freelancers experience an 'autonomy paradox', whereby they choose to work longer or 'unsocial' hours (Shevchuk et al. 2019) to meet project deadlines (Platman 2003, 2004), or to comply with last-minute client demands (Shevchuk et al. 2019) or requests for information, with a view to winning future work (Gold and Mustafa 2013). Where work flow is uncertain, freelancers might feel extra pressure to take on projects (Dex et al. 2000).

Freelancers report longer weekly hours on average than employees (e.g. Bell and La Valle 2003; Hyytinen and Ruuskanen 2007; European Commission 2016). Freelance fathers work long, atypical hours and undertake more weekend working than employee parents (Bell and La Valle 2003), and mothers often struggle to combine freelance work and childcare (e.g. Bell and La Valle 2003; Kirkwood and Tootell 2008; Annink and den Dulk 2012; Hilbrecht and Lero 2014; Johannsen Sevä and Öun 2015). Studies of publishing freelancers have found that evening and weekend working is widespread (Baverstock et al. 2015). Freelancers must also devote time that cannot be charged to clients (Evans et al. 2004) to project search, skill development and other activities (Shevchuk et al. 2019). Yet, despite often working long hours, the capacity to exercise autonomy over work-time is a source of satisfaction (Smeaton 2003; Croson and Minniti 2012).

Paradoxically, freelancers can work too few as well as too many hours (Baumberg and Meager 2015; CIPD 2017). Freelancers are more prone than employees to short hours working (Field and Forsey 2016) or irregular hours - and, therefore, to inadequate or volatile earnings (Hardy and Sanders 2015; FSB 2016; Lockey 2018). Unlike employees who may be laid off when there is no work, freelance workers can simply adjust their hours downwards, however financially damaging this might be, but without abandoning being a freelancer (Hatfield 2015). UK sources suggest some earn 
very little income from self-employment, which is probably an indicator of limited hours in many cases (HMRC 2018).

This chapter contributes to the literature on freelancing and working time in two ways. First, freelance workers might be expected to possess variable powers to control work-time, partly due to occupational differences in temporal boundedness (Cohen 2019) which depends, in part, on project characteristics such as the skills required or the need to work alongside others. Second, studies typically under-theorise the variability of client influence on freelancer capacity to control work-time. Gold and Mustafa's (2013) concept of client colonisation, referring to responding to client requests for information during 'unsocial' hours, is useful but if pressed too far ('work always wins') can easily overemphasise freelancer vulnerability to client pressure, allowing little room for freelancers to pursue their own work-time goals. Studies, however, do not always differentiate clients by type or resources, or, alternatively, they assume freelancers are dependent on large organisations in 'hierarchical subcontracting' relations (Stanworth and Stanworth 1997; Muehlberger 2007; O'Leary 2014; Morris et al. 2016). Client characteristics vary markedly and likely influence the parties' bargaining power and the struggle for work-time control in diverse ways.

\section{CONCEPTUALISING FREELANCER WORK-TIME CONTROL}

We now present an analytical framework to address our two research questions and to help fill the research gaps identified above. The framework sets out the connections between client type and resources, the demand for freelance labour and freelancers' work-time goals, resources and practices. Only clients can initiate freelance projects, by designing work assignments and outsourcing them to freelance workers, although freelancers may be able to shape their precise content, scheduling and remuneration. Clients must stipulate the work to be done, start and end dates, whether work must be performed at client premises or elsewhere, what counts as satisfactory performance, payment terms and who will be offered the work. Freelancers' clients and projects vary substantially in terms of a number of dimensions that potentially influence freelancers' bargaining power and their capacity to control working time (Table 1).

\section{- INSERT TABLE 1}


Clients are individuals as well as organisations, and organisational clients may be small or large, with varying levels of resources such as knowledge and finance. Relations with clients may be high-trust, or long-term, or low-trust and new. Projects vary with regard to content, timescale and the requirement for close synchronisation with co-workers' activities. Projects vary in terms of the skills they require for successful performance. They may consist of specific tasks of finite duration or comprise a 'retainer model' whereby clients engage freelancers for an indefinite period or with an intention of continuity (Camerani et al. 2015). ${ }^{3}$ Moreover, projects might require freelancers to perform work alone or to coordinate their activities closely with co-workers (employees or other freelancers). Projects also vary with regard to client requirements to work at client premises or whether freelancers may work at home. Projects and client relations are likely to vary across occupational groups, with implications for struggles over work-time control.

Freelancers' work-time goals can be conceptualised along two dimensions: work-time scheduling, the choice of precisely when to work within a given time period (for example, across the day, week, month, year); and, second, work duration, referring to the total hours worked during the period (Evans et al. 2004; Hilbrecht and Lero 2014). Freelancer capacity to control both scheduling and duration may vary over time (Cohen 2019). Freelancers schedule work-time by organising activities on one or more projects; work duration is the aggregate outcome of scheduling choices. As a consequence, freelancers' scheduling and duration goals are often in tension. Taking on new projects increases duration while simultaneously reducing the flexibility to schedule work as one would prefer. Working a 70-hour week, for instance, provides less choice over which hours to work than a 10-hour week, other non-work commitments being equal.

Freelancer work-time control is largely a function of the interaction of client type and resources, and level of demand, with freelancer decisions to take on specific projects in order to support a particular lifestyle, combining work and non-work preferences. Market conditions shape project offers and the fees/rates clients are prepared to pay. Project search and take-up are motivated by anticipated financial and non-financial rewards, enabled and constrained by personal, family and market circumstances; freelancers are therefore keen to avoid involuntary periods of non-work. Freelancers vary in their standard of living preferences, family responsibilities, 
household outgoings and reliance on freelance income to support a preferred lifestyle. Subject to there being sufficient client demand, freelancers may make an explicit tradeoff between work duration and income by accepting or declining (or not seeking) project offers.

Our specific focus is on how freelancers seek to preserve or extend control over working time, even where this sacrifices financial rewards. Freelancers might engage in various practices to control working time, subject to the requirement to meet client expectations. Such practices will likely vary with the parties' relative bargaining power. Freelancers possess variable capacities to control work-time, conditional upon their positioning within wider social structures, including relationships with clients. Relations with clients both constrain and enable freelancers' pursuit of work-time scheduling and work duration goals.

\section{METHODOLOGICAL APPROACH}

To answer the research questions, a qualitative research design was adopted. Qualitative strategies are well suited to capturing dynamic social processes, linking freelancers' perceptions and actions to the clients with whom they interact within the wider market and institutional setting that enables and constrains the parties' activities. The study draws on interview data from freelance workers in architecture and publishing (principally, copy-editors and proofreaders). Labour Force Survey data indicate that freelance working is a longstanding practice in both sectors (e.g. ONS 1992). In Q4, 2017, freelancers comprised approximately 25,000 (15\%) of the 166,000-strong publishing workforce in main jobs (ONS 2018a); a further 6,700 work freelance in publishing in a second job. In architecture, there were approximately 21,000 freelancers in main jobs (data are not available for second jobs).

The sample comprised 25 freelance workers, 13 in publishing and 12 architects (Table 2); we also consulted a number of professional and membership organisation representatives. ${ }^{4}$ Publishing freelancers were identified using the Society for Editors and Proofreaders online directory; Architects were identified using the Architects Registration Board and Royal Institute of British Architects online members' directories. We confined our interest to freelancers in Greater London (and Oxford, for publishing freelancers only), in order to make it easier to interview clients and freelance 
workers for the study and because both groups have a strong presence in these locations. Approximately $36 \%$ of publishing employment and $21 \%$ of architects are based in London (ONS 2018a). No sample sub-quotas were explicitly set for gender, age, place of work or other characteristic, although the online directories we used as our sampling frames were more likely to include established, experienced freelancers rather than younger practitioners.

\section{- INSERT TABLE 2}

Most respondents were female (15); and all were at least 40 years old. All respondents had worked freelance for at least three years, some for several decades. Our findings are therefore relevant primarily to experienced freelancers and likely reflect the online directories' listings we used to identify respondents. In publishing, we focused primarily on copy-editors and proofreaders. Copy-editing involves reviewing manuscripts for print and online publication to check spelling, grammar, punctuation, consistency, conformity to 'house style' and verifying factual claims; this often requires substantial academic, professional or practical knowledge of specific disciplines or fields. Proofreading involves reviewing copy-editors' work, text layout, and ensuring the typesetter has understood what the copy-editor intended. Projects vary in timescale depending on the length and complexity of manuscripts, for example, a couple of hours for a letter or a press release, through a couple of weeks for journal and magazine articles, and student theses, up to 1-2 months for a book. Publishing freelancers often provided other services, including developmental editing, project management, training and translation, partly because of a decline in copy-editing and proofreading projects. All publishing freelance respondents were educated to at least first degree level.

Architects are a more homogenous group in terms of job skills. To call oneself an architect in the UK requires completion of a 3-part programme of study and practical experience, and requires registration with the Architects Registration Board. All respondents reported a degree qualification (or equivalent if non-UK educated). Architects provided a range of services: initial, outline sketches as possible ideas for development; detailed design drawings; submitting drawings to the planning regulator for approval, (and resubmission, if necessary); finding construction professionals (surveyors, engineers) to provide specialist services direct to clients; and supervising construction work on-site. Projects involving all stages can take 1-2 years and possibly 
even longer where there are delays due to amendments to initial plans, changes in client circumstances (for instance, due to illness or financial concerns) or problems obtaining planning approval.

Face-to-face interviews were conducted with all respondents. Questions were asked regarding services provided, motivations for working freelance, methods of finding work, type of clients served, hours of work and reasons for variation, fee-setting processes, satisfaction with pay, hours and other aspects of work, and broader attitudes to freelancing as well as profile questions relating to education, work history and personal/family circumstances. Interviews were 64 minutes long on average.

All freelancer interviews were transcribed in full and coded using Nvivo, edition 11. Data were analysed guided by our conceptual framework, linking respondents' perceptions and actions to the wider market and personal/family contexts. Freelancer control over working time is connected causally to relations with clients, balancing pressures to meet multiple clients' expectations with the desire to preserve some degree of autonomy over hours of work. Respondents, and their references to particular clients, have been anonymised. The following sections present data on freelancers' struggles to control work duration and work-time scheduling.

\section{CONTROL OF WORK DURATION}

Freelancers' powers to control work duration are circumscribed in practice by the need to generate a flow of fee-paying clients sufficient to support a preferred lifestyle. High levels of client demand increase freelancers' bargaining power, enhancing their capacity to choose more satisfying projects with regard to project content, scheduling and remuneration. Freelancers seek to balance the competing pressures of generating an adequate volume of work to support a preferred lifestyle, while simultaneously seeking to avoid both excessively long or 'unsocial' hours and involuntary nonworking time. This section presents data on how freelance workers manage these competing pressures.

Architects were better placed to control work duration for several reasons. First, architects were typically in a more powerful position vis-à-vis clients than are publishing freelancers. Architects typically served individual clients, mostly homeowners, rather than organisational clients, and these clients were more dependent 
on the architect's professional expertise: 10 architects reported working mainly for individual clients at the time of interview; only two worked mainly for organisations (Architects 309, 401). Homeowners were heavily reliant on the architect's professional knowledge to determine project feasibility and timescales. All publishing freelancers, in contrast, served organisational clients, though a few had worked previously for individuals, for example, on student dissertations. Publishing clients, in particular, are extremely knowledgeable about the services they require freelancers to provide and capable of estimating project timescales, making it difficult for publishing freelancers to negotiate longer project deadlines or more generous fees or hourly rates. Where freelancers worked for non-publishing clients, they were better positioned to secure better payment terms and timescales.

Second, architects reported high levels of client demand, enabling them to be selective in accepting project offers. South West London has a large affluent homeowner population that can support a buoyant freelance architect market. Architects attributed high client demand to the combined effect of limited house price rises, the costs of moving and Stamp Duty Land Tax, each perhaps encouraging homeowners to refurbish current homes rather than buy new properties - although a number noted a slowdown following the UK referendum to leave the EU in 2016. Publishing freelancers, in contrast, reported fewer lucrative projects, particularly from conventional publishers. Many freelancers, particularly those working full-time, had sought new, better-paying clients in the education, hospitality and media sectors, for example (Publishing freelancers 102, 106, 107, 201, 204, 205, 206), and most had added new services to their copy-editing and proofreading skillsets.

Third, architects have a wider range of labour market alternatives available to them. Architects can work freelance or as an employee in a small or large practice if freelancing proves to be financially unrewarding. In sharp contrast, copy-editing and proofreading jobs are today largely organised on a freelance basis, following restructuring of the publishing sector in the late-1980s and early-1990s (Stanworth and Stanworth 1997; interviews with publishing industry respondents). Few employee jobs in these roles remain. Copy-editors and proofreaders must work freelance if they wish to continue in their chosen profession.

Architects' bargaining power was most obvious in their capacity to turn projects down. Respondents linked market demand, current workloads and the capacity to decline new work: 
"There's so much work round here, I think I'll always be turning work down" (Architect 302: female, 43, part-time)

Being busy, and anticipating a secure stream of future work, encouraged architects to be selective in choosing projects, turning down those perceived as low-paid or uninteresting, or where clients were perceived as likely to be "labour intensive" (Architect 306: male, 47, full-time).

Architects also reported the related practice of subcontracting projects, where respondents were too busy to undertake the work themselves, to other freelance workers. We found two cases of this in architecture (Architects 207, 307); respondents also reported examples from their earlier freelancing days of being the recipient of such outsourcing practices. Subcontracting projects was not common, but illustrates the high levels of client demand reported by sample architects.

I took a project on and then something else came on and I just didn't have the time to do everything. So I gave her - like that other person had done to me - a percentage of the fee and sort of said 'Run it how you like. Check in with me, but it has to be done in this time'. (Architect 307: female, 41, fulltime)

Because of their greater bargaining power in relation to clients, architects were able to choose the most lucrative or interesting projects, while subcontracting or declining other work. This enables architects to retain a high level of control over work duration while also achieving acceptable earnings. Publishing freelancers were less likely to report turning work down while also reporting lower levels of satisfaction with project fees/rates. Respondents in both sectors found it challenging to report 'usual' weekly hours. Most reported daily hours, accompanied by qualifications that these waxed and waned with planned and unplanned work and non-work contingencies (Table 3). Eighteen respondents worked as full-time freelancers (defined as 31 hours per week or more), six worked part-time, and one straddled the divide, depending on whether they worked a 3- or a 4-day week. At the high-end of the scale, two architects reported working 70 hours a week on occasion (Architects 301, 306) while, at the low end, one part-time architect reported working 16.5 hours a week (Architect 302) and a 
publishing freelancer reported working 4-5 hours per day three days a week (Publishing freelancer 103). All sample working-age males worked full-time, mostly adopting a 'family breadwinner' role. Working-age females' hours varied, depending on whether they were provisioning for a family and took primary responsibility for childcare. Semiretired freelancers, male and female, tended to work part-time.

\section{- INSERT TABLE 3}

Freelancers may choose to work a conventional Monday to Friday, 9-5 pattern, or, alternatively, during what are often termed 'unsocial' hours - in the evening, during the night, at weekends, and in the early morning. All architects and almost all publishing freelancers reported evening and weekend working at least some of the time, even those working part-time; only publishing freelancers 103 and 204 reported no recent evening or weekend working. A number of the sample reported a willingness to trade-off weekend working occasionally for time off for leisure and other activities during the conventional working week.

Freelancers often experience an 'autonomy paradox' (Huws et al. 1996), where they take on additional projects to increase income and trade-off time for nonwork activities - leisure and family/childcare. This paradox leads publishing freelancers and, to a lesser extent, architects, to occasionally take on projects that raise work duration beyond what freelancers would prefer.

I didn't really understand how difficult that would be. I thought that because I was so stressed in that job and I worked really, really hard and long hours, I thought that ... I would have more free time. And sometimes I do. But a lot of the time I don't, because depending on what clients want and juggling things around, I quite often don't have very much free time because ... there'll be a period where I'm working six days a week and some days when I work quite long hours. I probably do have more time - but it doesn't feel like I have more free time because I feel like I need to fill it with work, basically, and spend a lot of my time working - or doing work to get more work or admin and stuff like that. (Publishing freelancer 107: female, 50, full-time) 
Architects reported a long hours culture in the industry (Architects 308, 309, 401, 402, 403). These timekeeping norms were striking for one respondent working on client premises, although partly a consequence of his choice to compress four working days into three (Architect 309). But, arguably, such norms continue to influence architects who choose to become freelance. A long hours culture, combined with unpredictable client demands to 'juggle' multiple projects simultaneously, suggests that freelance architects may occasionally be prone to evening and weekend working.

I seem to work more hours now than I did when I wasn't [a freelancer], and more kind of weekends and evenings - which is ironic! The way work always is... you'll have two projects running simultaneously, and then both want what they need simultaneously ... So that's fine, architectural practices are well known for working late ... I find myself, there's no start and no end to my day really, unless I'm out doing something. So, it quite easily can slip into the evening ... (Architect 401: male, 47, full-time)

Seven publishing freelancers $(102,103,104,105,107,204,205)$ and one architect (307) reported experience of involuntary non-working time. This is a serious concern, particularly for full-time freelancers, as they are major contributors to household finances. Consequently, freelancers occasionally accepted low-paid projects where they perceived the alternative to be having no work at all. This practice was reported to be more common by publishing freelancers, partly because publishers' fees/hourly rates were widely perceived to be poor, having hardly increased at all in recent years. Accepting poorly-paid projects was more palatable where the client offered the prospect of a secure stream of future work, albeit modestly-rewarded.

...sometimes there are some articles, quite honestly, I would work on an article and the hourly rate that it converts to is less than the minimum wage. Why would I do it? Well, it's regular work, you can plan your year; you can plan your budget. That's why I do it. (Publishing freelancer 203: female, 65, part-time)

Part-time freelance workers found it difficult to report involuntary temporary/shorter hours as they did not work fixed weekly hours. Freelancers working part-time hours 
were more likely to be older, semi-retired individuals generally satisfied with their hours of work, though not necessarily with their freelance incomes. Some received other sources of income such as from pensions and property (Publishing freelancers 103, 203). Part-time freelancers have tacitly learned to live with lower incomes because they do not have fixed weekly hours in mind, have narrow client bases, are not proactively seeking additional projects or clients and are not keen to extend work duration.

Summarising, freelancer capacity to control work duration depends heavily on their bargaining power which, in turn, is heavily shaped by client type and resources, level of demand and client dependency on their expertise. Architects possessed greater capacity to choose lucrative projects and to turn down work because clients were typically affluent homeowners heavily dependent on the architect's professional expertise in determining project feasibility and timetables. Publishing freelancers, in contrast, generally worked for publishers who were more knowledgeable with regard to project scheduling and setting fees.

\section{WORK-TIME SCHEDULING PRACTICES}

This section presents data on how freelance workers seek to control work-time scheduling. Freelancers reported a range of practices intended to preserve or extend their control of scheduling, and to resist client colonisation of non-work time. These practices were diverse, but all related to the time-shifting of work obligations, so that freelancers were better able to schedule workloads as they wished, albeit explicitly or tacitly trading off the higher earnings that would result from greater project take-up. This supports Croson and Minniti's (2012) argument that autonomy over working time is often preferred to increased income. We now discuss some of the important practices freelance workers reported to control scheduling.

\section{Negotiating Attainable Project Timescales}

Both architects and publishing freelancers sought to build in 'slack' when negotiating project timescales with clients prior to starting work. Clients may, of course, resist setting longer deadlines where this might cause problems meeting their own customers' 
deadlines. Book publishers, for instance, organise copy-editing and proofreading functions as distinct phases in production cycles that connect complex supply chains linking authors (who submit manuscripts), jacket designers, layout specialists, illustrators, photographers and indexers, marketing activities and book launch as well as copy-editing and proofreading functions. There may be scope for some flexibility with book publishers although academic journals and magazines publishing monthly or quarterly may operate according to very strict deadlines that allow no flexibility to shift deadlines. Negotiating attainable timescales was common in both publishing and architecture.

I will just give myself plenty of time - and then I always meet the date. With some people, I deliver things early. So, for example, this book that I'm working on now, even though I want to finish it, they wanted it by next Wednesday. I said 'I'm just worried about getting it in the post in time. How about if it came on Friday, would it be a disaster?' And she said 'No, you can have it until then'. So I probably won't need it, and I'll probably deliver it by the Wednesday, but I just know that I've got that flexibility. Then it also means that when I deliver it early, she'll be like 'Oh! It's come early' which is quite good ... (Publishing freelancer 107: female, 45, full-time)

I make sure that I always promise things, hopefully, much further away than I need the time to do it because I always think it's better to promise it in two weeks and do it in a week and a half ... Whereas if you promise it in a week, and do it in a week and a half, there's a different mind-set from the client straight away ... I know that, actually, there are limited hours that I can work and so, as I say, I try not to over-promise. I try to stagger the start of projects, so I'm at different parts on different projects. For example, at the moment ... I'm not taking on any more projects till next year because I've already got so many on... (Architect 305: female, 45, full-time)

Freelancers might be better positioned to secure better project deadlines where clients are heavily dependent on the freelancer's expertise (architecture) or where they have long-term or high-trust relations with a client (publishing). Where clients can trust freelancers to meet deadlines and their own supply chains are not likely to be 
compromised, they may be willing to negotiate long deadlines. Because architects mostly serve homeowners, there is frequently no wider supply chain to consider.

\section{Working for Local Clients}

Time spent travelling is 'dead time' for freelancers unless they can charge it to clients. Architects working at home emphasised the time savings arising from working for local clients. Architect 306 reported a preference for clients 'within cycling distance' from his home and several others reported a strong preference for working for local clients (Architects 302, 303, 305, 307, 308, 402, 403). Local clients enabled freelancers to visit clients at their homes several times during the lifetime of a project, both planned and unplanned, and to absorb their cost within the budget. Architects reported meeting clients, and their spouses/partners, in person, to be important in assessing whether clients are genuine, likely to be 'labour intensive' and in building a rapport for a relationship that might last up to two years.

It's all house extensions and my furthest away client is about a 5 minute walk. It's crazy. It's just there's so much work around here; it's great. And the fact that my time is very limited, it just saves so many hours in travelling. (Architect 302: female, 43, part-time)

Architects were able to be selective in choosing local clients because of the level of demand for their services. In contrast, publishing freelancers typically work remotely for organisational clients whom they never meet, conducting business and communicating by email and telephone. Client location was therefore less important to publishing freelancers.

\section{Renegotiating Deadlines}

Requesting deadline extensions was reasonably common in publishing. Publishing freelancers reported publishers often delivered manuscripts or draft copy late while retaining the original deadline, compressing the time available to complete copy-editing and proofreading work. Respondents reported that clients varied in their willingness to grant extensions, partly contingent upon the parties' prior relations. 
But if you've kind of developed a good relationship with them and they know that you've delivered, even if you've only done two projects for them before and you delivered them both on time, then they kind of know they can trust you ... I think that's the most important thing really is having that trust that people know you're reliable and then if you do say 'Can I have an extra day?' Usually they've already written that in. (Publishing freelancer 107: female, 50, full-time)

For architects, project timescales were typically much longer and deadlines tended to be less rigid than in publishing. Delays arising from external contingencies that could not be anticipated at the planning stage were common. The discovery of on-site problems when supervising construction work such as hidden, natural obstacles or the legal rights of third parties often led to delays. .

\section{Declining Unplanned (and Uncosted) Client Requests}

Another common practice in architecture was to decline client requests for additional, unplanned - and therefore uncosted - project meetings or site visits. One architect described a subset of clients as 'labour intensive' (Architect 306), those making, or anticipated to make, substantial demands on their time, for example, by requesting additional meetings, or requesting additional information outside 'normal' work hours - at night, at weekends and even while on holiday having notified clients they would be taking time off. Other respondents referred to similar types of client (Publishing freelancers 103, 107; Architects 301, 304, 305, 306, 307).

\section{Home-Based Freelancing}

In principle, home-based working allows freelancers to schedule work as they wish, free from close client supervision. Freelancers are able to choose when to work and when to take breaks for leisure, childcare/family time, caring for elderly relatives, household chores and medical appointments. Working at home also eliminates commuting time (Publishing freelancer 102, 106, 203; Architect 302, 305, 308). Nearly all sample respondents, 22 of the 25 , were home-based; only three reported working at 
clients' premises at the time of interview (Publishing freelancer 104; Architects 309, 401). The power to control work-time scheduling was highly valued by all home-based respondents:

I think the most important is the times of day that I can work, because I'm not really a morning person. Well, I think, on average, I start work at 10.30 in the morning and finish at around 7 o'clock at night, and have a little break every now and then. And, also, I'm in control of when I work. So that is a big positive for being freelance. (Publishing freelancer 202: female, 50, fulltime)

If I want to take some hours off during the day to go and see an exhibition or do something like that, because it's easier to travel up to town, you don't have the rush, then I'll do that and I'll add those hours at the end of the day and work late in the evening. (Architect 402: male, 85, full-time)

Summarising, freelancers in both sectors reported a range of practices to control worktime scheduling, although architects possessed greater power to negotiate attainable deadlines, renegotiate deadline extensions, particularly on long projects, where external contingencies such as regulatory approval were unpredictable, and resist client requests for additional, unbudgeted meetings and site visits. This superior power rested on relations with homeowners dependent on their expertise and the high levels of client demand which enabled architects to be selective about projects. Publishing freelancers typically worked to shorter deadlines and often worked for clients knowledgeable about how long projects should take. Each of these factors enabled architects to schedule work-time in ways that enabled them to control work-time better than publishing freelancers.

\section{CONCLUSIONS AND IMPLICATIONS}

Freelance working reflects, in part, a desire to enjoy greater control over working life decisions. Using qualitative data from interviews with 25 skilled freelance workers in two professional sectors, publishing and architecture, this study has investigated the 
extent to which freelancers are able to control working time. We present two contributions to the literature on freelance working as a form of small business activity and working time. First, freelance workers vary in their capacity to control work-time, conditional upon parties' relative bargaining power. This rests, in turn, on a range of client and project characteristics. Freelancers serve different types of clients, form different kinds of relations with them, and take on variable levels of project work. Projects vary with regard to skill demands, timescale and spatio-temporal boundedness. Architects enjoyed high levels of client demand, and tended to work alone on long projects for individual homeowners, all of which enabled them to exercise a high level of influence over work scheduling and duration. Publishing freelancers, in contrast, tended to work for organisational clients on shorter projects where clients were able to estimate timescales, but with lower levels of client demand. Both architects and publishing freelancers typically worked on projects permitting home-based working that did not require close synchronisation with co-workers or clients.

Second, freelance workers engage in a variety of practices to preserve and extend control of work-time scheduling and duration, and to resist client colonisation of non-working time. These practices include winning new, better-paying clients that enable greater discretion over project selection and a range of deadline-shifting activities that trade off a more equitable distribution of working time in place of higher financial rewards. Freelancers are better positioned to control work-time where they stand in an equal bargaining relationship with clients. Architects serving homeowners are in a stronger position to shape project content and scheduling than publishing freelancers serving organisational clients because they possess greater knowledge relative to clients to influence the struggle for work-time control.

The principal implication of our work for theorising and research is to recognise the occupational heterogeneity of freelance work and its variable impact on struggles for work-time control. Working freelance does not necessarily facilitate greater control of working time. Freelancer capacity to control work-time varies across occupations, conditional upon client demand and a range of project and client characteristics, for example, client type, resources and relationship quality. Clients influence the struggle for work-time control through their project design, scheduling and allocation decisions. Temporal unboundedness may be a structural feature of freelance work (Cohen 2019) but there is variety in the extent of unboundedness, and the capacity of freelancers to manage it, even in skilled, professional occupations. 
Differences between professional and non-professional occupations are likely to be more marked. Freelance workers in non-professional occupations may have more limited powers to control working time.

\section{NOTES}

\footnotetext{
${ }^{1}$ We are grateful to the British Academy for funding the research upon which the chapter is based.

${ }^{2}$ We substitute the term 'freelance' for 'self-employed' when discussing prior research. This is not ideal because studies do not always distinguish the self-employed without employees - freelancers, as we define them here - from the self-employed with employees when presenting findings.

${ }^{3}$ Retainer arrangements might be scrutinised by national tax authorities where they believe freelancer/client relations are really relations between employer and employee. ${ }^{4}$ The data are taken from a larger study which also explored the views of freelancers' clients; these data are not reported here. We also conducted skype/telephone interviews with representatives from three professional and membership organisations to build our knowledge of the publishing industry prior to interviewing freelancers. Respondents were asked about recent changes in the industry, drivers of change and their implications for the use of freelance workers. We also obtained information from an architecture association representative.
} 


\section{REFERENCES}

Annink, A. and L. den Dulk (2012), 'Autonomy: the panacea for self-employed women's work-life balance?', Community, Work \& Family, 15 (4), 383-402.

Armstrong, V. (2013), 'Women's musical lives: self-managing a freelance career', Women: A Cultural Review, 24 (4), 298-314.

Bailey, C. and A. Madden (2017), 'Time reclaimed: temporality and the experience of meaningful work', Work, Employment and Society, 31 (1), 3-18.

Baines, S. and U. Gelder (2003), 'What is family friendly about the workplace in the home? The case of self-employed parents and their children, New Technology, Work and Employment, 18 (3), 223-234.

Barley, S. and G. Kunda (2006), 'Contracting: a new form of professional practice', Academy of Management Perspectives, 20 (1), 45-66.

Baumberg, B. and N. Meager (2015), 'Job quality and the self-employed: Is it still better to work for yourself?, in Felstead, A., Gallie, D. and Green, F. (eds), Unequal Britain at Work, , Oxford: Oxford University Press.

Baverstock, A., R. Blackburn and M. Iskandarova (2015), 'Who are the independent editors, how did they reach their role and what are their associated job satisfactions?', Learned Publishing, 28 (1), 43-53.

Bell, A. and I. La Valle (2003), Combining Self-Employment and Family Life, Bristol: Policy Press.

Benz, M. and B. Frey (2008), 'The value of doing what you like: Evidence from the self-employed in 23 countries', Journal of Economic Behavior \& Organization, 68 (34), 445-455.

Bögenhold, D. (2019), 'From hybrid entrepreneurs to entrepreneurial billionaires: observations on the socioeconomic heterogeneity of self-employment', American Behavioral Scientist, $\underline{\mathbf{6 3}}$ (2), 129-146.

Broughton, A., R. Gloster, R. Marvell, M. Green, J. Langley and A. Martin (2018), The experiences of individuals in the gig economy, BEIS, online at: https://www.employment-studies.co.uk/resource/experiences-individuals-gigeconomy 
Burtch, G, S. Carnahan and B. Greenwood (2018), 'Can you gig it? An empirical examination of the gig economy and entrepreneurial activity', Management Science, 64 (12), 5497-5520

Burke, A. (2012), 'The entrepreneurship enabling role of freelancers: theory with evidence from the construction industry', International Review of Entrepreneurship, 9 (3), 1-28.

Camerani, R., M. Masucci and J. Sapsed (2015), Brighton Fuse 2: The Brighton CDIT cluster three years later, Second Wave Firms Survey, online at: http://www.brightonfuse.com/brighton-fuse-reports-and-findings/

CIPD (2017), To Gig or Not to Gig? Stories from the Modern Economy, online at: https://www.cipd.co.uk/knowledge/work/trends/gig-economy-report

Cohen, R. L. (2019), 'Spatio-temporal un-boundedness: a feature, not a bug, of selfemployment', American Behavioral Scientist, 63 (2), 262-284. Croson, D. and M. Minniti (2012), 'Slipping the surly bonds: the value of autonomy in self-employment', Journal of Economic Psychology, 3 (2), 355-365.

Darcy, C., A. McCarthy, J. Hill and G. Grady (2012), 'Work-life balance: one size fits all? An exploratory analysis of the differential effects of career stage', European Management Journal, 30 (2), 111-120.

Dellot, B. (2014), Salvation in a Start-up? The origins and nature of the selfemployment boom, RSA report, online at: https://www.thersa.org/globalassets/pdfs/blogs/salvation-in-a-start-up-report180714.pdf

Dex, S., J. Willis, R. Paterson and E. Sheppard (2000), 'Freelance workers and contract uncertainty: the effects of contractual changes in the television industry', Work, Employment and Society, 14 (2), 283-305.

European Commission (2016), Employment and Social Developments in Europe 2015, Brussels: Directorate-General for Employment, Social Affairs and Inclusion, online at: http://ec.europa.eu/social/main.jsp?catId=738\&langId=en\&pubId=7859\&furtherPubs =yes

Evans, J., G. Kunda and S. Barley (2004), 'Beach time, bridge time, and billable hours: the temporal structure of technical contracting', Administrative Science Quarterly, 49 (1), 1-38. 
Federation of Small Businesses (FSB) (2016), Going it alone, Moving on up: Supporting Self-employment in the UK, online at: http://www.fsb.org.uk/docs/defaultsource/fsb-org-uk/fsb-supporting-self-employmentukf15f3abb4fa86562a286ff0000dc48fe.pdf?sfvrsn=0

Field, F. and A. Forsey (2016), Wild West Workforce: Self-employment in Britain's 'gig economy', online at: http://www.frankfield.co.uk/upload/docs/Wild\%20West\%20Workplace.pdf

Fraser, J. and M. Gold (2001), "“Portfolio workers": Autonomy and control amongst freelance translators', Work, Employment \& Society, 15 (4), 679-697.

Gold, M. and M. Mustafa (2013), “Work always wins': client colonisation, time management and the anxieties of connected freelancers', New Technology, Work and Employment, 28 (3), 197-211.

Hardy, K. and T. Sanders (2015), 'The political economy of 'lap dancing': contested careers and women's work in the stripping industry', Work, Employment \& Society, 29 (1), 119-136.

Hatfield, I. (2015), Self-Employment in Europe, online at: http://www.ippr.org/files/publications/pdf/self-employmentEurope Jan2015.pdf?noredirect $=1$

Hilbrecht, M. and D. Lero (2014), 'Self-employment and family life: constructing work-life balance when you're "always on"”, Community, Work \& Family, 17 (1), 20 42.

HM Revenue \& Customs (HMRC) (2018), Personal Incomes Statistics 2015-16, online at: https://www.gov.uk/government/collections/personal-incomes-statistics Huws, U. and others (1996), Teleworking and Gender, Brighton: Institute of Employment.

Hyytinen, A. and O.P. Ruuskanen (2007), 'Time use of the self-employed', Kyklos, 60 (1): 105-22.

Johannsen Sevä, I. and I. Öun (2015), 'Self-employment as a strategy for dealing with the competing demands of work and family? The importance of family/lifestyle motives', Gender, Work and Organisation, 22 (3), 256-272.

Kautonen, T., E. Kibler and M. Minniti (2017), 'Late-career entrepreneurship, income and quality of life', Journal of Business Venturing, 32 (3), 318-333. 
Keohane, N. (2017), Rules of Engagement: Reviewing self-employment and employment in the UK, Social Market Foundation, online at: http://www.smf.co.uk/wpcontent/uploads/2017/06/5600-SMF-PRISM-Report-WEB-AW-FINAL.pdf

Kirkwood, J. and B. Tootell (2008), 'Is entrepreneurship the answer to achieving workfamily balance?', Journal of Management \& Organization, 14 (3), 285-302.

Kitching, J. (2016), Exploring the UK Freelance Workforce in 2015, report for IPSE, online

at:

https://www.ipse.co.uk/resource/exploring the_uk_freelance_workforce_in_2016.htm $\underline{1}$

Kitching, J., and D. Smallbone (2012), 'Are freelancers a neglected form of small business?', Journal of Small Business and Enterprise Development, 19 (1), 74-91.

Lenton, P. (2017), Being your own boss: the many faces of self-employment, Sheffield Economic Research Paper Series, online at: https://www.sheffield.ac.uk/economics/research/serps/articles/2017 003

Lockey, A. (2018), Free Radicals, DEMOS, online at: https://www.demos.co.uk/project/free-radicals/

Mason, C. and D. Reuschke (2015), Home Truths: The true value of home-based businesses, a report for FSB Scotland, online at: https://www.fsb.org.uk/docs/defaultsource/fsb-org-uk/policy/rpu/scotland/assets/home-truths---final.pdf?sfvrsn=1

Morris, J., C. Farrell and M. Reed (2016), 'How the role of the independent editor is changing in relation to traditional and self-publishing', Human Relations, 69 (12), 2274-2297.

Muehlberger, U. (2007), 'Hierarchical forms of outsourcing and the creation of dependency', Organization Studies, 28 (5), 709-27.

Office for National Statistics (ONS) (1992), Quarterly Labour Force Survey, AprilJune 1992, ONS, London, data made available from the UK Data Archive.

Office for National Statistics (ONS) (2018a), Trends in Self-Employment in the UK: Analysing the characteristics, income and wealth of the self-employed, online at: https://www.ons.gov.uk/employmentandlabourmarket/peopleinwork/employmentande mployeetypes/articles/trendsinselfemploymentintheuk/2018-02-07

Office for National Statistics (ONS) (2018b), Quarterly Labour Force Survey, OctoberDecember, 2017. [data collection], UK Data Service. SN: 8326, http://doi.org/10.5255/UKDA-SN-8326-1

O'Leary, D. (2014), Going it Alone, DEMOS, online at: 
https://www.demos.co.uk/files/DEMOS_GoingitAlone_web.pdf?1409503024

Osnowitz, D. and K. Henson (2016), 'Leveraging limits for contract professionals: boundary work and control of working time', Work and Occupations, 43 (3), 326-360. Platman, K. (2003), 'The self-designed career in later life: a study of older portfolio workers in the United Kingdom', Ageing \& Society, 23 (3), 281-302.

Platman, K. (2004), 'Portfolio careers' and the search for flexibility in later life', Work, Employment and Society, 18 (3), 573-99.

Sappleton, N. and F. Lourenço (2016), 'Work satisfaction of the self-employed: the roles of work autonomy, working hours, gender and sector of self-employment', International Journal of Entrepreneurship and Innovation, 17 (2), 89-99.

Shevchuk, A., D. Strebkov and S. Davis (2018), 'The autonomy paradox: how night work undermines subjective well-being of internet-based freelancers', ILR Review, $\underline{\mathbf{7 2}}$ (1), 75-100.

Smeaton, D. (2003), 'Self-employed workers: calling the shots or hesitant independents? A consideration of the trends', Work, Employment and Society, 17 (2), 379-91.

Stanworth, C. and J. Stanworth (1997), 'Reluctant entrepreneurs and their clients - the case of self-employed freelance workers in the British book publishing industry', International Small Business Journal, 16 (1), 58-73.

Stephan, U., M. Hart and C.C. Drews (2015), Understanding Motivations for Entrepreneurship: A Review of Recent Research Evidence, online: https://research.aston.ac.uk/portal/files/15972188/Understanding_motivations for_ent repreneurship.pdf

Taylor Review (2017), Good Work: The Taylor Review of Modern Working Practices, online at: https://www.gov.uk/government/uploads/system/uploads/attachment_data/file/626772 /good-work-taylor-review-modern-working-practices.pdf

Tomlinson, D. and A. Corlett (2017), A Tough Gig? The Nature of Self-Employment in 21st Century Britain and Policy Implications, Resolution Foundation, online at: http://www.resolutionfoundation.org/publications/a-tough-gig-the-nature-of-selfemployment-in-21st-century-britain-and-policy-implications/

van Gelderen, M. and P. Jansen (2006), 'Autonomy as a start-up motive', Journal of Small Business and Enterprise Development, 13 (1), 23-32.

Vermeylen, G., M. Wilkens, A. Fromm and I. Biletta (2017), Exploring Self- 
Employment in Europe, Dublin: European Foundation for the Improvement of Living and Working Conditions.

Wainwright, T. and E. Kibler (2014), 'Beyond financialization: older entrepreneurship and retirement planning', Journal of Economic Geography, 14 (4), 849-864.

Williams, M., A. Broughton, N. Meager, K. Spiegelhalter, S. Johal and K. Jenkins (2017), The True Diversity of Self-Employment: Uncovering the different segments of the UK's self-employed workforce, online at: http://www.crse.co.uk/research/truediversity-self-employment 
Table 1 - Key Client and Project Characteristics Influencing the Struggle for Work-Time Control

\begin{tabular}{|l|l|}
\hline Client type \& resources & $\begin{array}{l}\text { Individual clients and freelancers may be more equally balanced in bargaining power, particularly where } \\
\text { freelancers possess specialist knowledge and have access to alternative projects and clients. Organisational } \\
\text { clients, particularly large ones, are more likely to possess the resources (knowledge, finance) to define project } \\
\text { content, scheduling and remuneration unilaterally. }\end{array}$ \\
\hline Client demand & $\begin{array}{l}\text { Freelance workers seek to balance competing pressures of generating a sufficient volume of projects to support a } \\
\text { preferred lifestyle, while simultaneously seeking to limit long or 'unsocial' hours and to minimise involuntary } \\
\text { non-working time. }\end{array}$ \\
\hline $\begin{array}{l}\text { Client relationship } \\
\text { quality }\end{array}$ & $\begin{array}{l}\text { Long-term/high-trust relations between freelancers and clients are likely to involve a greater degree of informal } \\
\text { negotiation over project scheduling than new, or low-trust relations. }\end{array}$ \\
\hline Project content & $\begin{array}{l}\text { The higher the occupational skill requirements, the greater the likelihood that freelancers possess the resources } \\
\text { (especially knowledge) to influence project scheduling and remuneration. }\end{array}$ \\
\hline Project timescale & $\begin{array}{l}\text { Short projects might prohibit deadline-shifting, unless clients are able to absorb delays within their own supply } \\
\text { chains or extend them to their own customers. Long projects may facilitate deadline-shifting, particularly where } \\
\text { risks to prompt completion can only be discovered after projects start (e.g. failure to obtain regulatory approval). }\end{array}$ \\
\hline Project synchronisation & $\begin{array}{l}\text { Projects requiring close synchronisation between freelancer and client, or between freelancer and co-workers, will } \\
\text { likely constrain freelancer control of work-time scheduling. Projects not requiring close synchronisation permit } \\
\text { greater freelancer control over scheduling. }\end{array}$ \\
\hline Work location & $\begin{array}{l}\text { Home-based freelance working, in principle, permits greater control over work-time scheduling. Working at } \\
\text { client premises enables clients to determine attendance and timekeeping norms. }\end{array}$ \\
\hline
\end{tabular}


Table 2 - Sample Profile

\begin{tabular}{|c|c|c|c|}
\hline $\begin{array}{l}\text { Respondent } \\
\text { code }\end{array}$ & $\operatorname{Sex}$ & Age & Year started freelance \\
\hline \multicolumn{4}{|c|}{ Publishing freelancers } \\
\hline 101 & Female & 74 & $1961 *$ \\
\hline 102 & Female & 67 & 1979 \\
\hline 103 & Male & 74 & $1982 *$ \\
\hline 104 & Male & 59 & 1990* \\
\hline 105 & Female & 66 & 1982 \\
\hline 106 & Female & 48 & 2013 \\
\hline 107 & Female & 50 & $1995^{*}$ \\
\hline 201 & Female & 61 & 1998 \\
\hline 202 & Female & 50 & 2011 \\
\hline 203 & Female & 65 & 2004 \\
\hline 204 & Female & 79 & 1986 \\
\hline 205 & Female & 56 & 2012 \\
\hline 206 & Female & 50 & 1997 \\
\hline \multicolumn{4}{|l|}{ Architects } \\
\hline 301 & Male & 65 & 1969 \\
\hline 302 & Female & 43 & 2010 \\
\hline 303 & Male & 60 & 1989 \\
\hline 304 & Male & 49 & 2000 \\
\hline 305 & Female & 45 & 2010 \\
\hline 306 & Male & 47 & 2009 \\
\hline 307 & Female & 41 & 2010 \\
\hline 308 & Female & 45 & 2006 \\
\hline 309 & Male & 43 & 2011 \\
\hline 401 & Male & 47 & 2014 \\
\hline 402 & Male & 85 & 1961 \\
\hline
\end{tabular}




\begin{tabular}{|l|c|c|c|}
\hline 403 & Male & 67 & 1986 \\
\hline \multicolumn{3}{|c|}{} \\
\hline $\begin{array}{l}\text { Notes: Respondent 205 holds a second freelance job. Starred }(*) \\
\text { interrupted career, with freelance working interspersed with periods of employment, } \\
\text { unemployment or labour market inactivity, for example, to raise a family. }\end{array}$ \\
\hline
\end{tabular}


Table 3 - Hours of Work

\begin{tabular}{|c|c|c|}
\hline Interview code & Full/Part-time Status; Hours of work & 'Unsocial Hours' working \\
\hline \multicolumn{3}{|c|}{ Publishing freelancers } \\
\hline 101 & Full-time: 5 days $x 9$ hours (45 hours) & Only very early morning, from 7am. \\
\hline 102 & $\begin{array}{l}\text { Full-time: } 8 \text { hours per day, start at } 12 \text {, work till } 8 \& \\
\text { sometimes later into the night ( } 40 \text { hours) }\end{array}$ & Occasional Sunday working, if absolutely necessary. \\
\hline 103 & $\begin{array}{l}\text { Part-time: although can work up to } 7 \text { hours a day, combined } \\
\text { with (mostly) voluntary periods of no work at all. }\end{array}$ & None recently. \\
\hline 104 & $\begin{array}{l}\text { Full-time: } 9.5-10.5 \text { hours, sometimes longer, when working } \\
\text { at client premises; at home, } 10 \text { hours, sometimes longer. }\end{array}$ & $\begin{array}{l}\text { Occasional evening working until 8.30/9.30 when based in } \\
\text { client's office. }\end{array}$ \\
\hline 105 & $\begin{array}{l}\text { Full-time: highly variable, } 10-12 \text { hours some days, then no } \\
\text { work for 2-3 weeks. }\end{array}$ & $\begin{array}{l}\text { Occasionally works } 12 \text { hours days and often at weekends to } \\
\text { meet a deadline }\end{array}$ \\
\hline 106 & Full-time: 5 days $x$ 7.5-8 hours (37.5-40 hours). & Occasionally works Sundays for 3 hours. \\
\hline 107 & $\begin{array}{l}\text { Full-time: } 30-35 \text { hours weekly average, but varying from } 20 \text { - } \\
50 \text {. }\end{array}$ & $\begin{array}{l}\text { Occasionally works at weekends to ensure work is done } \\
\text { before taking time off. }\end{array}$ \\
\hline 201 & Part-time: 20 hours per week. & $\begin{array}{l}\text { Works at weekends if necessary, reluctantly, mainly to } \\
\text { avoid work backlog when taking time off, though less often } \\
\text { than previously. }\end{array}$ \\
\hline 202 & Full-time: 5 days x 6.5 hours (32.5 hours) & $\begin{array}{l}\text { Occasionally works evenings, and very occasionally at } \\
\text { weekends, to meet a deadline. }\end{array}$ \\
\hline 203 & Part-time: 20 hours weekly average. & $\begin{array}{l}\text { Sometimes works until } 8.30 \mathrm{pm} \text { having taken time off for } \\
\text { leisure activities earlier in the day; occasionally until 2am, } \\
\text { and in the very early morning from 5am. }\end{array}$ \\
\hline 204 & $\begin{array}{l}\text { Part-time: works full-time hours when working, } \\
\text { interspersed with non-work periods. }\end{array}$ & None reported. \\
\hline 205 & $\begin{array}{l}\text { Part-time: no more than } 5 \text { hours a day. (Respondent holds a } \\
\text { second job and therefore works full-time overall). }\end{array}$ & Has worked evenings and weekends when necessary. \\
\hline 206 & Full-time: 5 days x 9-9.5 hours (45-47.5 hours). & $\begin{array}{l}\text { Quite often works } 4-5 \text { hours at weekends and occasional } \\
\text { evenings to meet deadlines. }\end{array}$ \\
\hline
\end{tabular}




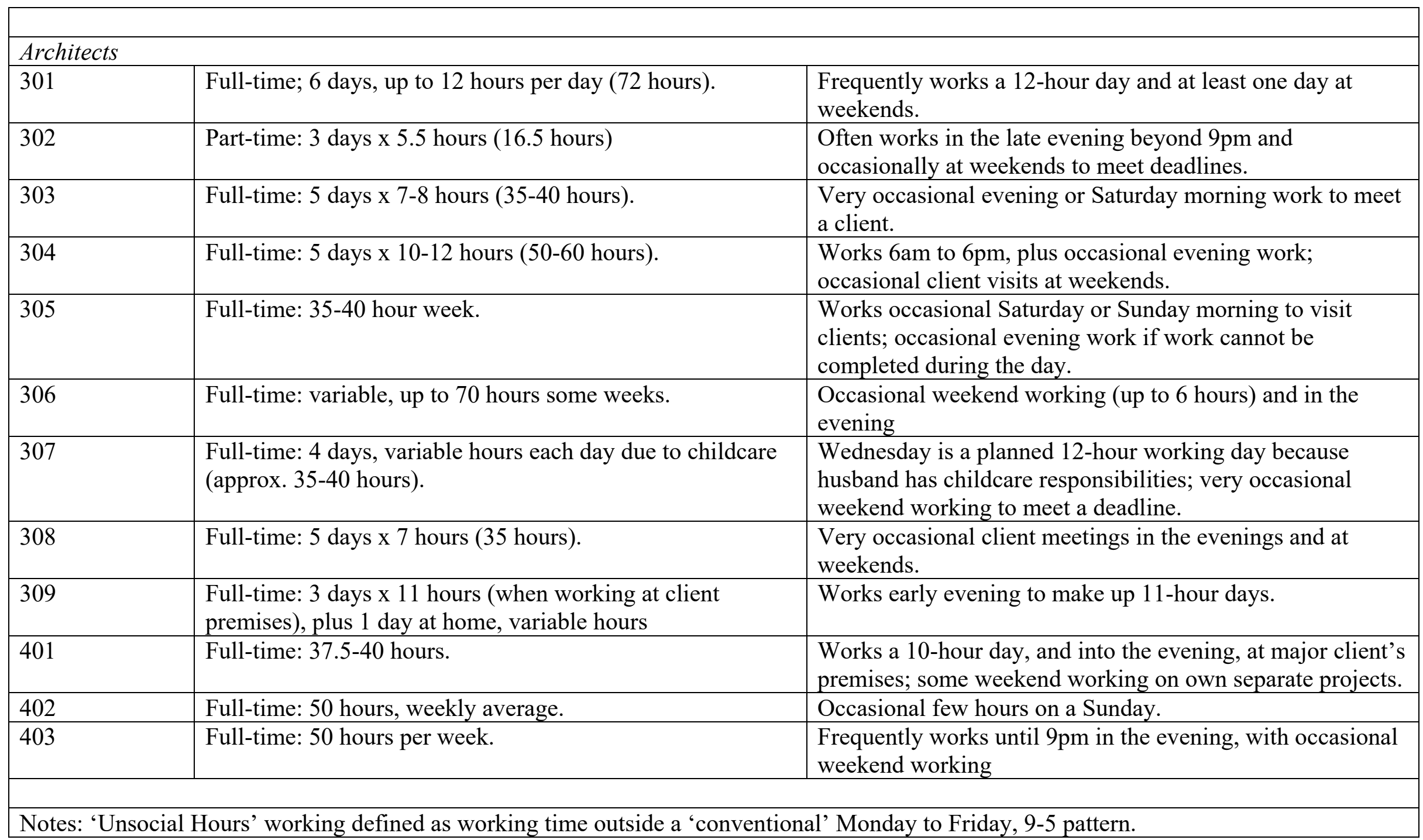


